\title{
Self-concealment, Social Network Sites Usage, Social Appearance Anxiety, Loneliness of High School Students: A Model Testing
}

\author{
Uğur Doğan ${ }^{1}$, Tuğba Seda Çolak ${ }^{2}$ \\ ${ }^{1}$ Muğla Sitkı Koçman University, Turkey \\ ${ }^{2}$ Duzce University, Turkey \\ Correspondence: Uğur Doğan, Muğla Sitkı Koçman University, Turkey
}

Received: February 28, 2016 Accepted: March 16, 2016 Online Published: April 4, 2016

doi:10.11114/jets.v4i6.1420

URL: http://dx.doi.org/10.11114/jets.v4i6.1420

\begin{abstract}
This study was tested a model for explain to social networks sites (SNS) usage with structural equation modeling (SEM). Using SEM on a sample of 475 high school students (35\% male, 65\% female) students, model was investigated the relationship between self-concealment, social appearance anxiety, loneliness on SNS such as Twitter and Facebook usage. It was hypothesized that SNS usage was predicted directly by self-concealment, was predicted indirectly by loneliness and social appearance anxiety. The SEM showed that SNS usage was significantly predicted directly by self-concealment and was significantly predicted indirectly by social appearance anxiety and loneliness. It was revealed that the fit indicies of the SEM created $\left(\mathrm{x}^{2}: 6.18\right.$, df: $2, \mathrm{x}^{2} / \mathrm{df}: 3.09, \mathrm{p}=.04558$, RMSEA $=.065$, GFI $=.99$, AGFI=.97, $\mathrm{NFI}=.98, \mathrm{NNFI}=.95, \mathrm{CFI}=.98, \mathrm{IFI}=.98, \mathrm{RMR}=.049$; SRMR=.028) in fit values. Based on the results social appearance anxiety, self-concealment and loneliness of high school students are remarkable predictors in terms of SNS usage.
\end{abstract}

Keywords: social appearance anxiety, self-concealment, loneliness, social network services usage

\section{Introduction}

Social network sites (SNS) such as Facebook and Twitter has become platforms which ensure users to share personal information, pictures and to connect with others. It is seen that SNS give an opportunity to have social interactions in an unreal world. People move to this unreal world, which can be defined as virtual environments, their identity via to post up own information, to share photographs, to specify their interests. These kind of interactions may be an indicator of youth's needs about being socialized like making friends and getting feedback from peers (Pempek, Yermolayeva, \& Calvert, 2009).

While research results in previous years showed that the most popular internet activities were to send e-mail a friend, to search information and the least popular ones were to chat to play game (Hills \& Argyle, 2003) and to communicate (Kraut, Patterson, Lundmark, Kiesler, Mukophadhyay, \& Scherlis, 1998); in recent years internet has transformed the most popular tool for social interaction via social networking sites (Hughes, Rowe, Batey, \& Lee, 2012). Young people use SNS because of several purposed like being source for social interaction, keeping communication with friends, making social capital etc. (Kalpidou, Costin, \& Morris, 2011; Lenhart \& Madden, 2007; Öztürk \& Akgün, 2012).

"Information and Communication Technology (ICT) Usage Survey on Households and Individuals" of Turkish Statistical Institute (TSI) (2015) shows that 42.921 .781 people use internet in Turkey. While $69.5 \%$ households have and use internet, $94.2 \%$ users are actively use it. If it is examined why they use internet so actively, it can be seen that sending message, making profile, sharing photos etc. on SNS. SNS usage statistics show increase in years 2011 to 2015 in Turkey. The rates showed 50.8\% users in 2011(TSI, 2011), this rate had increased 73.2\% in 2013(TSI, 2013), 78.8\% in 2014(TSI, 2014), and 80.9\% in 2015 (TSI, 2015). According to the statistics of the "We are social" website, Facebook is the mostly used SNS and has approximately 1.5 billion active users and Twitter is the second mostly used SNS and approximately 300 million active users in 2015 (www.wearesocial.com). According to the same study (Kemp, 2015), the rate of SNS users in Turkey is 52\%. This rates consist of 93\% Facebook members, and $72 \%$ Twitter members. This rates show that almost all users in Turkey have a membership at least one SNS and it can be concluded that SNS has a big role in people lives.

There is not one type of Social Network Sites user (Hargittai, 2007). Behavioral, psychological, and affective factors 
such as self-efficacy, computer anxiety, extroversion, and self-disclosure are correlated with techmology use (Schrock, 2008). This correlation reveals several kind of SNS user type. SNS offer service for all kind of people and can meet the several kind of need according to SNS's content (Hills \& Argyle, 2003). For example the most favorite two social network site Facebook and Twitter: Use of Facebook as social network service facilitate meeting new people and maintenance social relationships (Ellison, Steinfield, \& Lampe, 2007), Twitter facilitate to have joy by socializing (Hughes, Rowe, Batey, \& Lee, 2012). It shows difference according to gender like men use SNS to find new friends and women use SNS for maintenance friendship (Muscanell \& Guadagno, 2012).

Literature shows relation between loneliness and SNS usage. Some researches indicate that SNS usage increase loneliness (Kraut, Patterson, Lundmark, Kiesler, Mukophadhyay, \& Scherlis, 1998); at the same time some of them supports totally opposite of this finding (Shaw \& Gant, 2002).

Self-concealment is ordinary experience involves thoughts, feelings and information about a person which make him/her feel uncomfortable, stressful and avoid telling to others (Larson, 1994). Self-concealing is a way used mostly by introverted people who are quite, reserved, and shy (Van Egeren, 2009). Self-concealment found correlated with depression, self-reported anxiety, negative self-esteem and shyness and associated with less adaptive psychological adjustment (Ichiyama, Colbert, Laramore, Heim, Carone, \& Schmidt, 1993). Computer-mediated communication provides anonymity sense and results less anxiety than communicating face to face (Rice \& Markey, 2009).

Appearance is focal point for younger people in virtual relation (Stefanone, Lackaff, \& Rosen, 2011). Anxiety about appearance is very common and more highly on girls than boys (Cusumano \& Thompson, 1997; Jones, Vigfusdottir, \& Lee, 2004). Social appearance anxiety is defined as a kind of anxiety about being evaluated negatively in terms of ones' overall appearance (Hart, Flora, Palyo, Fresco, Holle, \& Heimberg, 2008). Appearance rejection sensitivity influences loneliness feelings. Concerns about appearance are subject to anticipatory anxiety for being rejected in terms of physical attractiveness. Anxiety of appearance can reflect anxiety of belongingness and self-esteem (Park, 2007). According to Stefanone, Lackaff, and Rosen (2011), if self-worth of a person is based on other people's evaluations about his/her appearance, it reflects behaviors on SNS. He/she may have tendency to emphasize his/her appearance by sharing more photos. Physical appearance based self-esteem level of adolescents increase when feedbacks on profile are positive, contrary to this negative feedback decrease the level (Valkenburg, Peter, \& Schouten, 2006).

Social appearance anxiety, self-concealment and loneliness can be handle as predictors of life quality. There is a gap in the literature about examining of SNS, Social appearance anxiety, self-concealment and loneliness via holistic perspective. There are some research in Turkey about motivation source of SNS usage, meeting friends on SNS offline or online, what types of SNS are used, how much time spend on SNS, etc. (Bilen, Ercan, \& Gülme, 2014; Dal \& Dal, 2015; Eren, Çelik, \& Aktürk, 2014; Göker, Demir, \& Doğan, 2010; İşman \& Albayrak, 2014; İşman \& Hamutoğlu, 2013; Öztürk \& Akgün, 2012; Şahin Baltacı, İşleyen, \& Özdemir, 2012; Vural \& Bat, 2010). In light of the above, it is thought that this study will fill a gap in the literature. Structural equation modeling (SEM) was used to predict Twitter and Facebook usage to signity the most popular SNS usage regarding social appearance anxiety, self-concealment and loneliness of high school students. Figure 1 shows hypothesis model of the study.

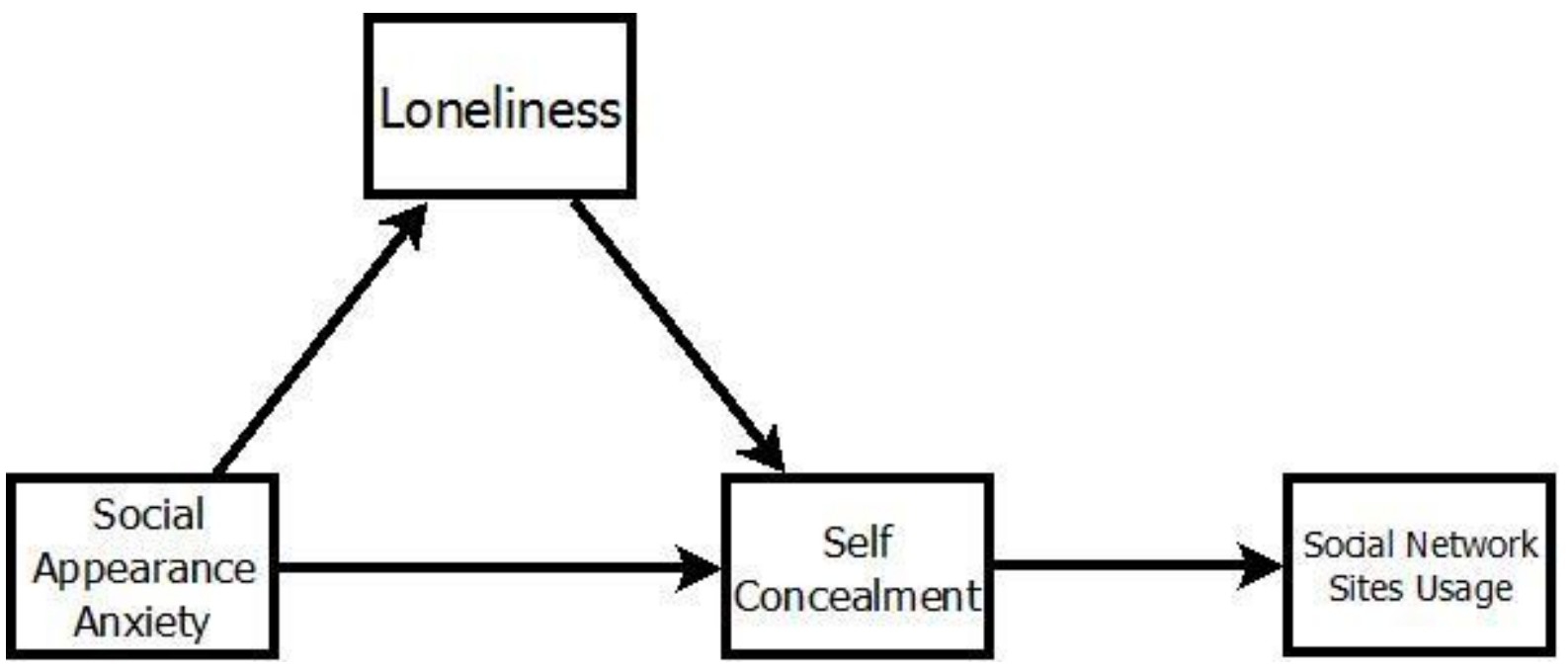

Figure 1. SEM of SNS usage, social appearance anxiety, self-concealment and loneliness

(Hypothetical Model) 


\section{Method}

\subsection{Participants and Procedure}

The universe of this research consists of all high school students who are studying in Turkey in the 2013-2014 academic year. Sample of research consist of randomly selected 4 high schools from 15 high schools in Bolu. Participants are voluntary 475 9th, 10th, 11th grade students from these 4 high schools students in Bolu. Accordingly, the participants are 169 male (35\%) and 306 female (65\%) students. Participants' ages ranked between from 14 to 20. Participants voluntarily participated in the research. During completion of the scales, it was guaranteed to be anonymous and confidential.

\subsection{Measures}

Questionnaire of SNS usage was administered to measure students' SNS usage in the current study. In addition, Social Appearance Anxiety Scale was used to measure social appearance anxiety. Self-Concealment was measured with the Self-Concealment Scale and UCLA Loneliness Scale was used to measure loneliness. Information about the researchers' that adapted scales to Turkish and reliability and validity scores of adopted measures was given below.

Social Network Sites Use: The participants' use of SNS was determined by a questionnaire which consisted a question: "To what extent do you use Social Network Sites in a day? (Such as Facebook, Twitter)".

Social Appearance Anxiety Scale: The scale developed by Hart, Flora, Palyo, Fresco, Holle, and Heimberg (2008), Doğan (2010) made adaptation of the scale. This scale is a 16 items self-reported measurement scale on a 5-point Likert-type scale $(1=$ not at all to $5=$ extremely). Higher score indicate higher social appearance anxiety level. Exploratory factor analysis for structural validity of the scale accounted for $53.4 \%$ total variance for Turkish adaption study. Results of confirmatory factor analysis indicated that the model was well-fit and Chi-Square value $\left(x^{2}=143.79\right.$, $\mathrm{N}=254, \mathrm{p}=0.01$ ) which was calculated for the adaptation of the model was found to be significant. The goodness of fit index values of the model were RMSEA=0.051, NFI=0.98, CFI=0.99, IFI=0.99, RFI=0.98, GFI=0.93 and AGFI=0.90. The Cronbach alpha internal consistency coefficient of Turkish form was .93. For test-retest reliability the scale was administered to 86 college students twice in two weeks. Pearson correlation coefficient was .85 .

Self-Concealment Scale: The scale developed by Larson and Chastain (1990) and Turkish form was adopted by Deniz and Çok (2010). This scale is an10 items self-reported measurement scale on a 5-point Likert-type scale (1=not at all to $5=$ extremely). Higher score indicate higher secrecy level. Exploratory factor analysis for structural validity of the scale accounted for $43.76 \%$ total variance for Turkish adaption study. Confirmatory factor analysis results showed that the model indexes were well-fit and Chi-Square value $\left(x^{2}=100.34, N=370, s d=33, p=0.000\right)$ which was calculated for the adaptation of the model was found to be significant. The goodness of fit index values of the model were RMSEA= 0.074, $\mathrm{SRMR}=0.050, \mathrm{GFI}=0.93, \mathrm{AGFI}=0.89, \mathrm{CFI}=0.97 \mathrm{andNNFI}=0.96$. The Cronbach alpha internal consistency coefficient of Turkish form was .86.

UCLA Loneliness Scale: Russell, Peplau, and Ferguson (1978) were developed the scale and Turkish adaptation was made by Demir (1989). This scale is a 20 items self-reported measurement scale on a 4-point Likert-type scale (1=I often feel this way to 4=I never feel this way). Higher score indicate higher loneliness level. Turkish translation of the scale was made with "criteria validity" technique. As result of the criteria validity, correlation between scores of UCLA loneliness scale and social introversion subdimension of multidimensional depression scale is .82 and correlation between scores of UCLA loneliness scaleand beck depression inventory is .77 . The test-retest reliability value of the scale was found .94 , internal consistency coefficient was .95 .

\subsection{Procedure}

The scales were implemented to the students in groups in the classroom. The measures were counter balanced in implementation. Before the implementation of scales, purposes of the study were told to all participants. In this research, Pearson correlation coefficient was utilized to determine the relationships between variables and SEM utilized to contributions of the social networks sites use to social appearance anxiety, self-concealment and loneliness in high school students. Data gathered form 12th grade students were not included in to the analysis because of university entrance exam made them reluctant.

\section{Results}

\subsection{Data Analysis}

Lisrel 8.80 and IBM SPSS 20.00 (Statistical Package for the Social Sciences) package programs were used for the statistical analyses of the data. Within this context, Pearson product-moment correlation analysis and SEM were used for analyzing the SNS usage to social appearance anxiety, self-concealment and loneliness in high school students. SEM is a statistical technique which uses the combination of statistical data and qualitative causal assumptions in order to test 
and estimate causal relations. The data analysis model is tested parallel to the measurement data available in order to find out to what extent the model fits the data. The causal assumptions which form the basis of this model may be verified by means of being tested against the data. Factor analysis, path analysis, and regression analysis demonstrate special cases of SEM (Grimm \& Yarnold, 1995; Kline, 2011).

\subsection{Descriptive Data and Inter-correlations}

Descriptive findings and correlation coefficients related to SNS usage, social appearance anxiety, self-concealment and loneliness are shown in Table 1.

Table 1. Correlation matrix and descriptive findings for variables used in SEM

\begin{tabular}{lllllll}
\hline Variables & Mean & Sd & $\mathbf{1}$ & $\mathbf{2}$ & $\mathbf{3}$ & $\mathbf{4}$ \\
\hline 1-Social Networks Sites Use & 2.45 & 0.89 & 1 & & & \\
2-Social Appearance Anxiety & 36.77 & 14.04 & $.13^{* *}$ & 1 & & \\
3-Self-Concealment & 24.06 & 9.06 & $.24 * *$ & $.39^{* *}$ & 1 & \\
4-Loneliness & 39.33 & 7.48 & .03 & $.41^{* *}$ & $.40^{* *}$ & 1 \\
** & & & & & &
\end{tabular}

Table 1 presents correlations between pair of variables of model. As can be seen, SNS use have a significant and positive relationship with social appearance anxiety $(r=.13)$, social appearance anxiety $(r=.24)$ but no significant relationship with loneliness ( $\mathrm{r}=.03$ ).

\subsection{Structural Equation Modeling}

In this study, the model was constructed by means of testing the relationships between the social networks sites use to loneliness, social appearance anxiety and self-concealment in high school students, using SEM. Before analysis, measurement models were calculated and the fit indices of this model are presented in Table 2.

Table 2. Goodness of fit statistics for social appearance anxiety, self-concealment, loneliness

\begin{tabular}{lllllllll}
\hline Variables & $\boldsymbol{X}^{2}$ & $\mathbf{d f}$ & $\boldsymbol{X}^{2} / \boldsymbol{d} \boldsymbol{f}$ & $\mathbf{R M S E A}$ & $\mathbf{S R M R}$ & $\mathbf{C F I}$ & NNFI & GFI \\
\hline Self-Concealment & 139.12 & 34 & 4.09 & .07 & .04 & .97 & .96 & .95 \\
Loneliness & 554.23 & 167 & 3.31 & .06 & .05 & .96 & .96 & .90 \\
Social Appearance Anxiety & 369.05 & 102 & 3.61 & .07 & .03 & .98 & .98 & .92 \\
\hline
\end{tabular}

Note: $x^{2}=$ Chi-square; $d f=$ degrees of freedom; RMSEA = root mean square error of approximation; SRMR $=$ standardized root mean square residual; $C F I=$ comparative fit index; NNFI = non-normed fit index; GFI = goodness of fit index.

According to most of applied criteria, all measurement models showed acceptable fit indices. After specification of the measurement models, the SEM was evaluated using the Robust Maximum Likelihood estimation method with Lisrel 8.80. Figure 2 shows standardized estimates of the model. SEM was performed to predict SNS usage by social appearance anxiety, SC and loneliness and the results are given in Figure 2. Figure 2 illustrates the final model (standardized coefficients).

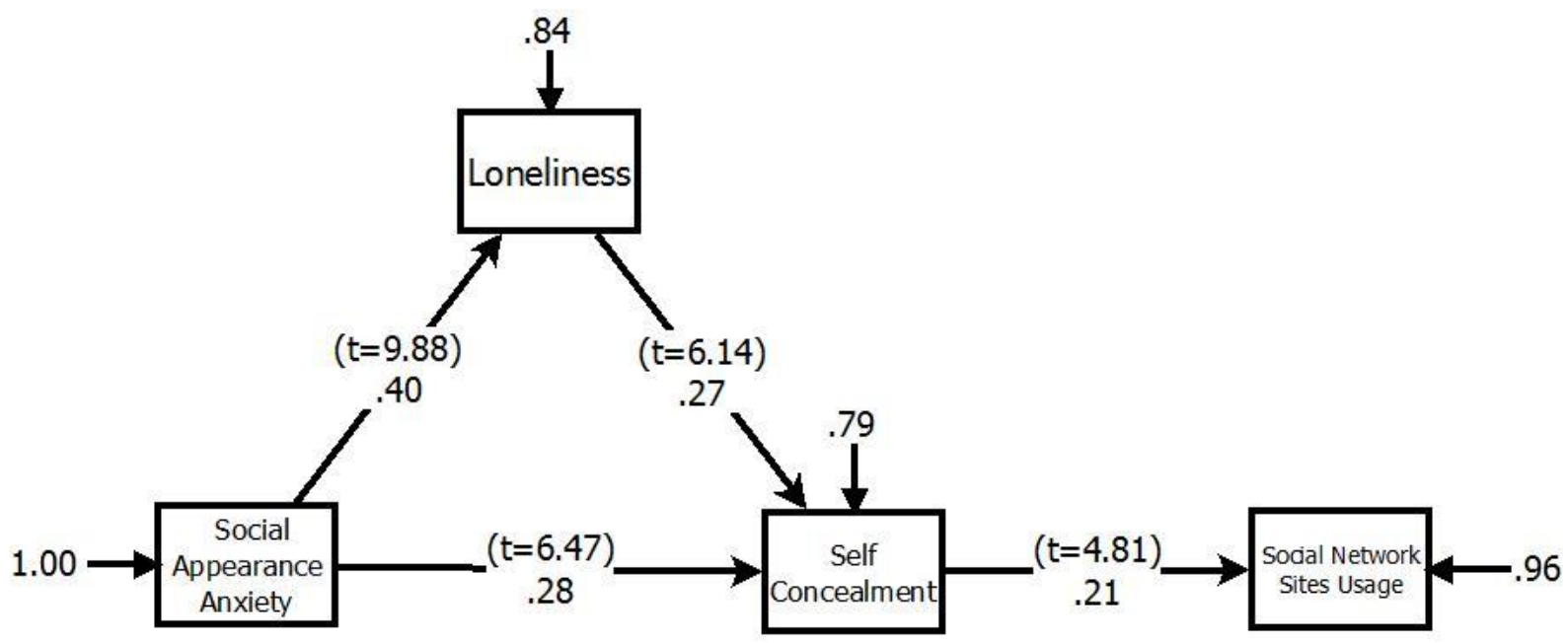

\section{Chi-Square $=6.18, \mathrm{df}=2, \mathrm{P}$-value $=0.04558, \mathrm{RMSEA}=0.065$}

Figure 2. SEM of SNS usage, social appearance anxiety, self-concealment and loneliness (Final Model) 
According to the data obtained the total points of social appearance anxiety, self-concealment and loneliness predict the SNS usage between 21 and .40. Figure 2 shows whether the variables are consistent or not is analyzed. As can be seen in Figure 2, the data obtained fit well model $\left(\chi^{2}=6.18, \mathrm{df}=2, \chi^{2} / \mathrm{df}=3.09, p=.04558, \mathrm{RMSEA}=.065\right.$, GFI=.99, AGFI=.97, $\mathrm{NFI}=.98, \mathrm{NNFI}=.95, \mathrm{CFI}=.98, \mathrm{IFI}=.98, \mathrm{RMR}=.049 ; \mathrm{SRMR}=.028)$. Path coefficients ranged from .21 and .40 .

\section{Discussion}

The paper revealed that social appearance anxiety, self-concealment and loneliness are important predictors of SNS. If reasons of internet usage are considered, it is seen that people use SNS for several purposes. Research results show that especially, adolescents and young adults use SNS actively for social reasons. Some of them use internet as a tool for expression of their real or fantasy identity. Social appearance anxiety may increase demand of becoming invisible. By this way self-concealment and loneliness may start to take role for people with social appearance anxiety, and SNS becomes a platform where the people may express themselves as they want.

Self-concealment predict SNS use directly. SNS users could conceal their real identity and create a new one. There are some reasons to create a new identity. One of them is privacy. SNS users could hide their real identity because of security concerns. Another reason is SNS enable people to be a person who they want to be. Being anonymous may increase feelings of control interaction. No one has to know real identity or features of the person. By this way, SNS users can hide their unwanted, stressful features and be a person who he/she thinks other people approve. They can hide unwanted features like physical appearance, shyness, low self-esteem and so on. If research results analysed in the light of the result, it can be seen that previous researches support the paper. For example Taddicken and Jers (2011) showed that SNS users can manage their information consciously according to requirements of respondents. Impression managements are major motive for actively participating in SNS (Krämer \& Haferkamp, 2011) and people can choose the information about themself that they want to share and manage them according to how they want to present themselves (Krämer \& Winter, 2008).

Although there are some researches show direct effect of loneliness on SNS use (Amichai-Hamburger \& Ben-Artzi, 2000; Moody, 2001; Sum, Mathews, Hughes, \& Campbell, 2008), the paper revealed that loneliness and social appearance anxiety is indirectly predict SNS use by the effect of self-concealment for adolescents. This finding is supported by previous researches. Lonely and introverted users choose passive activities on SNS instead of social sharing (Amichai-Hamburger, Wainapel, \& Fox, 2002; Ryan \& Xenos, 2011). One of the major problems is appearance for adolescents. They spent amount of their time in front of mirror. Because of appearance anxiety, adolescents avoid from social environments and this avoidance was seen especially in age of puberty (Rapee \& Spence, 2004). Sheldon (2008) revealed that students who feel anxiety about face to face communication, use SNS to spend time or feel less lonely. As it is also indicated by Pempek, Yermolayeva, and Calvert (2009), while the individuals feel more anxiety in face to face communication, they feel less anxiety with communication via SNS. Individuals who feel anxiety about self-appearance, hide themselves via opportunities of SNS, and meet the need of keep in touch with others. By this way adolescents can decrease anxiety which will be lived because of appearance and feel as if they are social.

There are certain limitations in the study. The purposive question "To what extent do you use Social Network Sites in a day? (Such as Facebook, Twitter)" was asked to state students' SNS usage. It is assumed that all students use SNS, they are active users of Facebook and Twitter, and analysis was conducted accordingly. It would be more efficient to include students using SNS actively. How students' SNS use characterizes has not been examined. Whether SNS usage is normal or not was ignored. Morever, the most popular SNSs as Twitter and Facebook were examined, but the other recent popular SNSs as Vine, Whatsapp, Periscope, and Swarm, were not taken into consideration. It may be more inclusive that studies including recent popular SNSs.

It is seen that there are several studies about that there is relationship between SNS and loneliness in literature. Contrary to popular belief, SNS usage does not make the adolescent isolate. Students who suffer loneliness tend to use SNS to socialize. According studies, student especially freshman use more SNS than other grades. The mentioned interactions and communications are established through SNS. Similarly, according to findings of same study, high school students with high levels of social appearance anxiety feel lonelier, this is an expected result. In spite of not being directly predict to SNS, loneliness predicts indirectly predict to SNS via self-concealment. So, loneliness effect self-concealment in high school students, SNS provides opportunity for self-concealment. Students, who feel anxiety about self-appearance, will isolate themselves from society and will be lonely. Mentioned relationship pattern show up again when the students experience loneliness. Overall, the finding of study showed that social appearance anxiety effect self-concealment and loneliness; in the same time social appearance anxiety effect directly SNS via self-concealment and loneliness. 


\section{References}

Amichai-Hamburger, Y., \& Ben-Artzi, E. (2000). The relationship between extraversion and neuroticism and the different uses of the internet. Computers in Human Behavior, 16(4), 441-449. http://dx.doi.org/10.1016/S0747-5632(02)00014-6

Amichai-Hamburger, Y., Wainapel, G., \& Fox, S. (2002). " On the internet no one knows i'm an introvert": Extroversion, neuroticism, and internet interaction. CyberPsychology \& Behavior, 5(2), 125-128. http://dx.doi.org/10.1089/109493102753770507

Bilen, K., Ercan, O., \& Gülme, T. (2014). Sosyal ağların kullanım amacı ve benimseme süreci; Kahramanmaraş Sütçü İmam üniversitesi örneği (Intended uses and adoption process of social networks; Kahramanmaras Sütçü İmam university example). Journal of Research in Education and Teaching, 3(1), 115-123.

Cusumano, D. L., \& Thompson, J. K. (1997). Body image and body shape ideals in magazines: Exposure, awareness, and internalization. Sex Roles, 37(9-10), 701-721. http://dx.doi.org/10.1007/BF02936336

Dal, N. E., \& Dal, V. (2015). Kişilik özellikleri ve sosyal ağ sitesi kullanım alışkanlıkları: Üniversite öğrencileri üzerine bir araştırma (Personality traits and social network sites usage habits: A research on university students). Mehmet Akif Ersoy University Journal of Social Sciences Institute, 6(11), 144-162.

Demir, A. (1989). UCLA Yalnızlık ölçeğinin geçerlik ve güvenirliği (UCLA loneliness scale: Validity and reliability study). Turkish Journal of Psychology, 41(2), 14-18.

Deniz, M., \& Çok, F. (2010). Psychometric properties and adaptation of the self-concealment scale to the turkish adolescents. Elementary Education Online, 9(1), 424-432.

Doğan, T. (2010). Sosyal görünüş kaygısı ölçeğinin (SGKÖ) Türkçe uyarlaması: Geçerlik ve güvenirlik çalışması (Adaptation of the social appearance anxiety scale (SAAS) to Turkish: A validity and reliability study). Hacettepe University Journal of Education, 39, 151-159.

Ellison, N. B., Steinfield, C., \& Lampe, C. (2007). The benefits of Facebook "friends:" Social capital and college students' use of online social network sites. Journal of Computer - Mediated Communication, 12(4), 1143-1168. http://dx.doi.org/10.1111

Eren, F., Çelik, İ., \& Aktürk, A. O. (2014). Ortaokul öğrencilerinin facebook algısı: Bir metafor analizi (Secondary school students' perceptions of Facebook: A metaphor analysis). Kastamonu Education Journal, 22(2), 635-648.

Göker, G., Demir, M., \& Doğan, A. (2010). Ağ toplumunda sosyalleşme ve paylaşım: Facebook üzerine ampirik bir araştırma (Socialization and sharing in the network society: An empirical research on facebook). e-Journal of New World Sciences Academy, 5(2), 183-206.

Grimm, L. G., \& Yarnold, P. R. (1995). Reading and understanding MORE multivariate statistics. Washhington: American Psychological Association.

Hargittai, E. (2007). Whose space? Differences among users and non - users of social network sites. Journal of Computer - Mediated Communication, 13(1), 276-297. doi: 10.1111/j.1083-6101.2007.00396.x

Hart, T. A., Flora, D. B., Palyo, S. A., Fresco, D. M., Holle, C., \& Heimberg, R. G. (2008). Development and examination of the social appearance anxiety scale. Assessment, 15(1), 48-59. doi: 10.1177/1073191107306673

Hills, P., \& Argyle, M. (2003). Uses of the Internet and their relationships with individual differences in personality. Computers in Human Behavior, 19(1), 59-70.

Hughes, D. J., Rowe, M., Batey, M., \& Lee, A. (2012). A tale of two sites: Twitter vs. Facebook and the personality predictors of social media usage. Computers in Human Behavior, 28(2), 561-569.

http://dx.doi.org/10.1016/j.chb.2011.11.001

Ichiyama, M. A., Colbert, D., Laramore, H., Heim, M., Carone, K., \& Schmidt, J. (1993). Self-concealment and correlates of adjustment in college students. Journal of College Student Psychotherapy, 7(4), 55-68. http://dx.doi.org/10.1300/J035v07n04_05

İşman, A., \& Albayrak, E. (2014). Ağlardan facebook'un eğitime yönelik etkililiği (Effectiveness of facebook as a social network in education). Trakya University Journal of Education, 4(1), 129-138.

İşman, A., \& Hamutoğlu, N. B. (2013). Sosyal ağlarin eğitim-öğretim sürecinde kullanılması ile ilgili karma öğrenme öğrencilerinin görüşleri: Sakarya üniversitesi örneği (Blended student's views about using social networks in education period: A case study in Sakarya university). International Journal of New Trends in Arts, Sports \& Science Education, 2(3), 61-67. 
Jones, D. C., Vigfusdottir, T. H., \& Lee, Y. (2004). Body image and the appearance culture among adolescent girls and boys: An examination of friend conversations, peer criticism, appearance magazines, and the internalization of appearance ideals. Journal of Adolescent Research, 19(3), 323-339. http://dx.doi.org/10.1177/0743558403258847

Kalpidou, M., Costin, D., \& Morris, J. (2011). The relationship between Facebook and the well-being of undergraduate college students. Cyberpsychology, Behavior, Social and Networking, 14(4), 183-189.

http://dx.doi.org/10.1089/cyber.2010.0061

Kemp, S. (2015). Social, Digital \& Mobile Worldwide in 2015. Retrieved January 20, 2015, from http://wearesocial.net/blog/2014/01/social-digital-mobile-worldwide-2014

Kline, R. B. (2011). Principles and practice of structural equation modeling (3 ed.). New York: Guilford press.

Krämer, N. C., \& Haferkamp, N. (2011). Online self-presentation: Balancing privacy concerns and impression construction on social networking sites. In S. Trepte \& R. Leonard (Eds.), Privacy Online: Perspectives on Privacy and Self-Disclosure in the Social Web (pp. 127-141): Springer.

Krämer, N. C., \& Winter, S. (2008). Impression management 2.0: The relationship of self-esteem, extraversion, self-efficacy, and self-presentation within social networking sites. Journal of Media Psychology, 20(3), 106-116. http://dx.doi.org/10.1027/1864-1105.20.3.106

Kraut, R., Patterson, M., Lundmark, V., Kiesler, S., Mukophadhyay, T., \& Scherlis, W. (1998). Internet paradox: A social technology that reduces social involvement and psychological well-being? American psychologist, 53(9), 1017-1031. http://dx.doi.org/10.1037/0003-066X.53.9.1017

Larson, D. G. (1994). Self-concealment: Implications for stress and empathy in oncology care. Journal of psychosocial oncology, 11(4), 1-16. doi: 10.1300/J077V11N04_01

Larson, D. G., \& Chastain, R. L. (1990). Self-concealment: Conceptualization, measurement, and health implications. Journal of Social and Clinical psychology, 9(4), 439-455. doi: 10.1521/jscp.1990.9.4.439

Lenhart, A., \& Madden, M. (2007). Teens, Privacy and Online Social Networks. Washington, DC: Pew Internet \& American Life Project.

Moody, E. J. (2001). Internet use and its relationship to loneliness. CyberPsychology \& Behavior, 4(3), 393-401. http://dx.doi.org/10.1089

Muscanell, N. L., \& Guadagno, R. E. (2012). Make new friends or keep the old: Gender and personality differences in social networking use. Computers in Human Behavior, 28(1), 107-112. http://dx.doi.org/10.1016/j.chb.2011.08.016

Öztürk, M., \& Akgün, Ö. E. (2012). Üniversite öğrencilerinin sosyal paylaşım sitelerini kullanma amaçları ve bu sitelerin eğitimlerinde kullanılması ile ilgili görüşleri (University students' purposes in using social networking sites,and their opinions on using these sites in education). Sakarya University Journal of Education, 2(3), 49-67.

Park, L. E. (2007). Appearance-based rejection sensitivity: Implications for mental and physical health, affect, and motivation. Personality and Social Psychology Bulletin, 33(4), 490-504. http://dx.doi.org/10.1177/0146167206296301

Pempek, T. A., Yermolayeva, Y. A., \& Calvert, S. L. (2009). College students' social networking experiences on Facebook. Journal of Applied Developmental Psychology, 30(3), 227-238. http://dx.doi.org/10.1016/j.appdev.2008.12.010

Rapee, R. M., \& Spence, S. H. (2004). The etiology of social phobia: Empirical evidence and an initial model. Clinical Psychology Review, 24(7), 737-767.

Rice, L., \& Markey, P. M. (2009). The role of extraversion and neuroticism in influencing anxiety following computer-mediated interactions. Personality and Individual Differences, 46(1), 35-39. http://dx.doi.org/10.1016/j.paid.2008.08.022

Russell, D., Peplau, L. A., \& Ferguson, M. L. (1978). Developing a measure of loneliness. J Pers Assess, 42(3), 290-294. http://dx.doi.org/10.1207/s15327752jpa4203_11

Ryan, T., \& Xenos, S. (2011). Who uses Facebook? An investigation into the relationship between the Big Five, shyness, narcissism, loneliness, and Facebook usage. Computers in Human Behavior, 27(5), 1658-1664. http://dx.doi.org/10.1016/j.chb.2011.02.004

Şahin, B. H., İşleyen, F., \& Özdemir, S. (2012). Eğitim fakültesi öğrencilerinin romantik ilişki durumları ve sosyal ağ kullanımlarına göre etkileşim kaygısı ve sosyal destek algılarının incelenmesi (The investigation of interaction anxiety and social support perceptions of the faculty of education students according to the romantic relationship 
status and social network use). Mersin University Journal of the Faculty of Educationi, 8(2), 25-36.

Schrock, A. (2008). Examining social media usage: Technology clusters and social network site membership. First Monday, 14(1).

Shaw, L. H., \& Gant, L. M. (2002). In defense of the Internet: The relationship between Internet communication and depression, loneliness, self-esteem, and perceived social support. CyberPsychology \& Behavior, 5(2), 157-171. http://dx.doi.org/10.1089/109493102753770552.

Sheldon, P. (2008). The relationship between unwillingness-to-communicate and students' Facebook use. Journal of Media Psychology, 20(2), 67-75. http://dx.doi.org/10.1027/1864-1105.20.2.67

Stefanone, M. A., Lackaff, D., \& Rosen, D. (2011). Contingencies of self-worth and social-networking-site behavior. Cyberpsychology, Behavior, and Social Networking, 14(1-2), 41-49. http://dx.doi.org/10.1089/cyber.2010.0049

Sum, S., Mathews, R. M., Hughes, I., \& Campbell, A. (2008). Internet use and loneliness in older adults. CyberPsychology \& Behavior, 11(2), 208-211. http://dx.doi.org/10.1089/cpb.2007.0010

Taddicken, M., \& Jers, C. (2011). The uses of privacy online: Trading a loss of privacy for social web gratifications? In T. Sabine \& R. Leonard (Eds.), Privacy online: Perspectives on privacy and self-disclosure in the social web (pp. 143-156): Springer.

TSI. (2011). Hanehalkı Bilişim Teknolojileri Kullanım Araştırması (Information and Communication Technology (ICT) Usage Survey on Households and Individuals). Ankara.

TSI. (2013). Hanehalkı Bilişim Teknolojileri Kullanım Araştırması (Information and Communication Technology (ICT) Usage Survey on Households and Individuals). Ankara.

TSI. (2014). Hanehalkı Bilişim Teknolojileri Kullanım Araştırması (Information and Communication Technology (ICT) Usage Survey on Households and Individuals). Ankara.

TSI. (2015). Hanehalkı Bilişim Teknolojileri Kullanım Araştırması (Information and Communication Technology (ICT) Usage Survey on Households and Individuals). Ankara.

Valkenburg, P. M., Peter, J., \& Schouten, A. P. (2006). Friend Networking Sites and Their Relationship to Adolescents' Well-Being and Social Self-Esteem. CyberPsychology \& Behavior, 9(5), 584-590. http://dx.doi.org/10.1089/cpb.2006.9.584

Van Egeren, L. F. (2009). A cybernetic model of global personality traits. Personality and Social Psychology Review, 13(2), 92-108. http://dx.doi.org/10.1177/1088868309334860

Vural, Z. B. A., \& Bat, M. (2010). Yeni bir iletişim ortamı olarak sosyal medya: Ege üniversitesi iletişim fakültesine yönelik bir araştırma (Social media as a new communication environment: A research on Ege university faculty of communication). Journal of Yasar University, 20(5), 3348-3382. 